\title{
TECHNICAL EFFICIENCY OF TURKISH PUBLIC HOSPITALS' INTENSIVE CARE UNITS: MULTIPLE INPUT - OUTPUT TECHNOLOGIES AND DISTANCE FUNCTIONS
}

\author{
Asst. Prof. Emre ATILGAN*
}

\begin{abstract}
This paper presents the technical efficiencies of Turkish public hospitals' intensive care units (ICUs) using the Stochastic Distance Functions under the multiple input-out production technologies. Two estimation models are used in the paper; input-oriented and output-oriented stochastic distance functions which both are described by the translog production technology. The efficiency analysis is made with the sample of 385MoHhospitals for the year 2014. The mean inefficiency of the sample ICUs is found to be \%12 (mean efficiency score=0.88) in the input-oriented efficiency model. On the other hand, the mean output-oriented inefficiency is estimated \%21. The results of the paper suggest that, in both of input and output oriented model definition, there is significant increasing returns to scale in ICUs' service production. Teaching and branch hospital ICUs are found to be more efficient than the others.
\end{abstract}

Keywords: Distance Functions, Stochastic Frontier Analysis, Technical Efficiency, Intensive Care Units

JEL Classification: D24, $I 11$

\section{TÜRKIYYE KAMU HASTANELERİ YOĞUN BAKIM SERVISLERININ TEKNIK ETKİNLİĞİ: ÇOKLU GİRDİ - ÇIKTI TEKNOLOJİLERİ VE UZAKLIK FONKSIYYONLARI}

\section{$\ddot{O Z Z}$}

Bu çalışmada çoklu girdi-çıktı üretim teknolojileri altında, Türkiye kamu hastaneleri yoğun bakım servislerinin teknik etkinlikleri Stokastik Uzaklık Fonksiyonları ile analiz edilmektedir. Çalışmada translog üretim teknoloji ile tanımlanmış girdi yönlü ve çıktı yönlü stokastik uzaklık fonksiyonları olmak üzere, iki tahmin modeli kullanılmaktadır: Etkinlik analizi Sağllk Bakanlı̆̆ına bağlı 385 hastanenin 2014 yılı verileriyle gerçekleştirilmiştir. Örneklemdeki yoğun bakım servislerinin ortalama girdi yönlü etkisizlik değeri \%12 (ortalama etkinlik skoru=0.88) bulunmuştur. Diğer taraftan ortalama çıktı yönlü etkinsizlik \%21 olarak hesaplanmıştır. Çalışmanın sonuçları, girdi ve çıktı yönlü modellerin her ikisinde de yoğun bakım servislerinin hizmet üretiminde ölçeğe göre artan

\footnotetext{
* Trakya University, Faculty of Health Sciences, Department of Health Management, emreatilgan@trakya.edu.tr
} 
getirinin bulunduğunu göstermektedir. Eğitim ve dal hastanelerinin yoğun bakım servisleri, diğer hastaneleri göre daha etkin bulunmuştur.

Anahtar Kelimeler: Uzaklık Fonksiyonları, Stokastik Sınır Analizi, Teknik Etkinlik, Yoğun Bakım Servisleri

JEL Sinıflaması: D24, I11

\section{INTRODUCTION}

Technical inefficiency of a firm describes the deviation from its production frontier and the econometric measurement of the inefficiency is related with the estimation of that deviation. The parametric methods developed prior to the Stochastic Frontier Analysis (SFA) (see for ex. Winsten (1957); Aigner and Chu (1968); Afriat (1972);Richmond (1974)) associated the inefficiency with all deviations from the specified production limits. The main shortcoming of these approaches is that they assume the frontier is not affected by random cases. With the discovery of SFA by pioneer works of Aigner, Lovell, and Schmidt (1977) and Meeusen and Van den Broeck (1977), it became possible to decompose the deviation from the production/cost frontier into a random or classical error and a deterministic error, which is assumed to represent the production/cost inefficiency.

Beginning with Wagstaff (1989), who examined the efficiency of Spanish hospitals, health care applications of SFA are being used by a growing number of studies conducted in Europe as well as the United States. The efficiency studies in health sector focus mostly on the hospital efficiency. There are few studies concerning ICUs' efficiencies. Puig-Junoy and Rué-Monné (1998) is an example study that used the Data Envelopment Analysis (DEA) to estimate the technical inefficiencies of ICUs in Spain.

There is no yet a study in the literature that investigates the efficiencies of ICUs in Turkey. The empirical literature which concerns efficiency in the Turkey health system also focuses on the hospital efficiency and the studies generally use DEA (see for ex. Sahin and Ozcan (2000); Özgen, Sahin, and Gülcü (2008); Sahin (2009); Sahin, Ozcan, and Ozgen (2011)). Atilgan and Çalişkan (2015) and Atilgan (2015)are the pioneer studies that use the Stochastic Frontier Analysis for evaluation Turkish hospital efficiencies.

In this paper, the technical efficiencies of the public hospitals' intensive care units (ICUs) is investigated by using the Stochastic Distance Functions under the multiple input-out hospital production technologies in Turkey. This paper is the first study of its kind nationally. 
The rest of the paper is organized as follows. In the second section, the Stochastic Frontier Analysis and Distance Functions are introduced. A detailed discussion of the model and the variables are presented in the third section. In the fourth section, SFA estimates and the results are interpreted and the last section concludes.

\section{STOCHASTIC FRONTIER ANALYSIS AND DISTANCE FUNCTIONS}

The purpose of SFA is to decompose variations from production/cost frontier into a random or classical error and a deterministic error, which is assumed to represent the production/cost inefficiency. The basic unrestricted SFA production function can be presented as ${ }^{1}$ :

$$
Y_{i t}=x_{i t} \beta+\left(V_{i t}-U_{i t}\right)
$$

In the equation (1), $t=1, \ldots, T$ represent time and;

- $Y_{i t}$, is the production of firm "i" in the time period "t",

- $x_{i t}$ is the input vector of firm "i" in the time period " $\mathrm{t}$ ",

- $\beta$ is the parameters to be estimated.

- $V_{i t}$ is the random error assumed to be distributed $V_{i} \sim$ iid $N\left(0, \sigma_{v}^{2}\right)$

- $U_{i t}=U_{i} \exp (-\eta(t-T)), \quad U_{i t}$ represents the inefficiency and assumed to be distributed as $U_{i} \sim$ iid $N\left(\mu, \sigma_{U}^{2}\right)$ where $\eta$ is the parameter to be estimated.

- $V_{i t}$ and $U_{i t}$ are distributed independently.

The Equation (1) describes a production function that a single output is produced with a set of inputs. This kind of production description brings some limitations when one tries to investigate the technical efficiency in a multiple-output industry. Hospitals are natural examples of multiple-output firms as in hospitals many different outputs are produced with a given set of inputs. For example, a physician or a nurse can be used to produce inpatient and outpatient services within a workday. Using distance functions in SFA is a way to overcome the mentioned joint production problem. On the other hand, distance functions could be used in the circumstances where neither of the revenue maximizing and/or cost minimizing behaviors are existed in the analyzed sector, as the public sector has many examples (Coelli and Perelman, 1996).

The distance functions could be described both input-oriented and output oriented. The inputoriented distance function simply represents the degree to which a hospital could decrease its input use

\footnotetext{
${ }^{1}$ In the equation the panel data version of SFA is given. This paper uses a cross sectional SFA model due to data limitations.
} 
without changing its outputs. On the other hand, the output-oriented distance function represents the degree to which a hospital could expand its output without changing its input use. From these definitions, we can understand that distance functions give the magnitude of the deviation from the best or the frontier production limits.

The production technology of the firm using the output set, $P(x)$, which represents the set of all output vectors $y \grave{o} R_{+}^{M}$, which can be produced using the input vector $x \grave{o} R_{+}^{K}$ is:

$$
P(x)=\left\{y \grave{o} R_{+}^{M}: x \text { can produce } y\right\}
$$

Technical efficiency refers to producers' choices to allocate the resources at their disposal to obtain the maximum possible output from given inputs, or to use the minimum possible inputs in the production of a given level of outputs. Therefore, the analysis of technical efficiency may be defined as either output-oriented or input-oriented (Coelli, Rao, O'Donnell, and Battese, 2005)

The distance functions could be used to provide a characterization of the structure of the multiple input - output production technology. When $x=\left(x_{1}, \ldots, x_{N}\right) \grave{o} R_{+}^{N}$ is the vector of inputs used to produce the vector of outputs $y=\left(y_{1}, \ldots, y_{M}\right) \grave{o} R_{+}^{M}$, where $P(x)$ represents the production technology of the firm and $L(y)$ represents the set of all input vectors, the input and the output distance functions are defined as following(Shepherd, 2015):

The output distance function:

$$
D_{o}(x, y)=\min \{\mu: y / \mu \in P(x)\}
$$

defines the minimum amount by which an output vector can be radially expanded and still remains producible with a given input vector.

The input distance function:

$$
D_{i}(y, x)=\max \{\lambda: x / \lambda \in L(y)\}
$$

defines the maximum amount by which an input vector can be radially contracted and still the production of output vector remains feasible.

In the multiple-output production frontiers, for any number of outputs is produced, the output oriented measure of technical efficiency is given by the function:

$$
T E_{o}(x, y)=[\max \{\phi: \phi y \in P(x)\}]^{-1}
$$

The input oriented measure of technical efficiency is given by the function: 


$$
T E_{i}(y, x)=\min \left\{\theta: D_{i}(y, \theta x) \geq 1\right\}
$$

\subsection{Stochastic Distance Functions}

The multiple - output stochastic frontier can be written as:

$$
D_{0 i}\left(x_{i}, y_{i}, z_{i} ; \beta\right)=\exp \left(v_{i}-u_{i}\right)
$$

Where $D_{0 i}\left(x_{i}, y_{i}, z_{i} ; \beta\right)$ is the output distance function, $x_{i}$ is the vector of inputs, $y_{i}$ is the vector of outputs, $z_{i}$ is the vector of hospital specific characteristics other than inputs of the $\mathrm{i}^{\text {th }}$ hospital and $\beta$ is the vector of technology parameters. On the left side of the equation, $v_{i}$ is the statistical noise which assumed to be distributed $\mathrm{N}\left(0, \sigma^{2}\right)$, and $u_{i}$ is the positive deviation from the cost frontier which represents the technical inefficiency(Coelli et al., 2005). The stochastic frontier in terms of the input distance function can be given as follows:

$$
D_{I i}\left(x_{i}, y_{i}, z_{i} ; \beta\right)=\exp \left(v_{i}-u_{i}\right)
$$

Equations (7) and (8) can be rewritten as following in order to form stochastic distance function models:

$$
\begin{aligned}
& 1=D_{0 i}\left(x_{i}, y_{i}, z_{i} ; \beta\right) \cdot \exp \left(v_{i}-u_{i}\right) \\
& 1=D_{I i}\left(x_{i}, y_{i}, z_{i} ; \beta\right) \cdot \exp \left(v_{i}-u_{i}\right)
\end{aligned}
$$

In order to convert equations (9) and (10) into estimable models, linear homogeneity in $D_{0}$ and $D_{I}$ should be imposed for outputs and inputs respectively.

$$
\begin{aligned}
& D_{0 i}\left(x_{i}, \varphi y_{i}, z_{i} ; \beta\right)=\varphi D_{0 i}\left(x_{i}, y_{i}, z_{i} ; \beta\right) \forall \varphi>0 \\
& D_{I i}\left(\varphi x_{i}, y_{i}, z_{i} ; \beta\right)=\varphi D_{I i}\left(x_{i}, y_{i}, z_{i} ; \beta\right) \quad \forall \varphi>0
\end{aligned}
$$

Coelli and Perelman (1996) present that $D_{0}$ and $D_{I}$ functions could be used in the models by normalizing the outputs/inputs respectively with any output/input variables:

$$
\begin{array}{ll}
D_{0 i}\left(x_{i}, y_{i}, z_{i} ; \beta\right) / y_{1 i}=D_{0 i}\left(x_{i}, y_{i}^{*}, z_{i} ; \beta\right) & \text { for } y_{i}^{*}=\frac{y_{i}}{y_{1 i}} \\
D_{\mathrm{I} i}\left(x_{i}, y_{i}, z_{i} ; \beta\right) / x_{1 i}=D_{0 i}\left(x_{i}^{*}, y_{i}, z_{i} ; \beta\right) & \text { for } x_{i}^{*}=\frac{x_{i}}{x_{1 i}}
\end{array}
$$

Then we have: 


$$
D_{0}\left(x_{i}, y_{i}, z_{i} ; \beta\right)=y_{1 i} D_{0}\left(x_{i}, \frac{y_{i}}{y_{1 i}}, z_{i} ; \beta\right)
$$

$$
D_{\mathrm{I}}\left(x_{i}, y_{i}, z_{i} ; \beta\right)=x_{1 i} D_{\mathrm{I}}\left(\frac{x_{i}}{x_{1 i}}, y_{i}, z_{i} ; \beta\right)
$$

When the Equations (15) and (16) are substituted in Equations (9) and (10) and both sides are divided by $y_{1 i}$ ve $x_{1 i}$ respectively, then we have the compound error models as:

$$
\left(y_{1 i}\right)^{-1}=D_{0}\left(x_{i}, \frac{y_{i}}{y_{1 i}}, z_{i} ; \beta\right) \cdot \exp \left(v_{i}-u_{i}\right)
$$

$$
\left(x_{1 i}\right)^{-1}=D_{\mathrm{I}}\left(\frac{x_{i}}{x_{1 i}}, y_{i}, z_{i} ; \beta\right) \cdot \exp \left(v_{i}-u_{i}\right)
$$

\section{MODEL, DATA AND VARIABLES}

\subsection{Model}

In order to estimate the Equations (17) and (18), the functional form or the production technology of the model should be identified. In the hospital SFA studies, popular and commonly used forms are the translog and the Cobb-Douglas production function forms. The translog production function, which characterizes a flexible functional form, is commonly used by the researchers to avoid modeling errors or/and to get flexibility in the specification of input and output relations without having a-priory assumptions ${ }^{2}$ (Rosko and Mutter, 2008). In this study, we also use the translog production technology to estimate the technical efficiencies of Turkish public hospitals' intensive care units. The output-oriented and the input-oriented SFA production functions that is used in the estimations are given by the Equation (19) and (20) respectively as follows:

\footnotetext{
${ }^{2}$ For detailed information see Berndt and Christensen (1973), Christensen, Jorgenson, and Lau (1973) and Caves, Christensen, and Tretheway (1980).
} 


$$
\begin{aligned}
& -\ln y_{1 i}=\alpha_{0}+\sum_{i=1}^{\mathrm{N}} \alpha_{i} \ln y_{i h}^{*}+\sum_{j=1}^{\mathrm{K}} \beta_{j} \ln w_{j h}+\frac{1}{2} \sum_{i=1}^{\mathrm{N}} \sum_{k=1}^{\mathrm{N}} \alpha_{i k} \ln y_{i h}^{*} \ln y_{k h}^{*}+\frac{1}{2} \sum_{i=1}^{\mathrm{K}} \sum_{k=1}^{\mathrm{K}} \beta_{i k} \ln w_{i h} \ln w_{k h} \\
& +\sum_{i=1}^{\mathrm{N}} \sum_{k=1}^{\mathrm{K}} \varphi_{i k} \ln y_{i h}^{*} \ln w_{k h}+\sum_{m=1}^{\mathrm{M}} \psi_{m} E_{m}+v_{i}-u_{i} \\
& -\ln x_{1 i}=\alpha_{0}+\sum_{i=1}^{\mathrm{N}} \alpha_{i} \ln y_{i h}+\sum_{j=1}^{\mathrm{K}} \beta_{j} \ln x_{j h}^{*}+\frac{1}{2} \sum_{i=1}^{\mathrm{N}} \sum_{k=1}^{\mathrm{N}} \alpha_{i k} \ln y_{i h} \ln y_{k h}+\frac{1}{2} \sum_{i=1}^{\mathrm{K}} \sum_{k=1}^{\mathrm{K}} \beta_{i k} \ln x_{i h}^{*} \ln x_{k h}^{*} \\
& +\sum_{i=1}^{\mathrm{N}} \sum_{k=1}^{\mathrm{K}} \varphi_{i k} \ln y_{i h} \ln x_{k h}^{*}+\sum_{m=1}^{\mathrm{M}} \psi_{m} E_{m}+v_{i}-u_{i}
\end{aligned}
$$

where; $\alpha, \beta, \varphi$ ve $\psi$ are the parameters to be estimated and $h: 1, \ldots ., \mathrm{H}$ counts for the hospitals' intensive care units;

$y_{i h}$ : is the $\mathrm{i}^{\text {th }}$ output of hospital h (normalized)

$w_{i h}:$ is the $\mathrm{i}^{\text {th }}$ input of hospital $\mathrm{h}$ (normalized)

$E_{m h}:$ Control variables used to proxy input and/or output heterogeneity

In the equations $v_{i}$ is the random error term and $u_{i t}$ is the inefficiency term as described above. In order to estimate the inefficiency effects in one step, the cross sectional version of the inefficiency effects model of Battese and Coelli (1995)is used, thus the efficiency term $u_{i}$ is assumed to be distributed as $N\left(z_{i} \delta, \sigma_{u}^{2}\right)$ where $z_{i}$ is the vector of hospital specific variables thought to effect the inefficiency.

\subsection{Data and Variables}

The efficiency analysis is made with the sample of 385 Turkish MoH hospitals' intensive care units for the year 2014. The dataset has been obtained from the Ministry of Health. In the models, two classes of variables as a measure of output, five input variables, five control variables and three inefficiency effect variables are used. The variable definitions and summary statistics are presented in Table (1). 
Table 1. Variable Definitions and Summary Statistics

\begin{tabular}{|c|c|c|c|c|c|}
\hline Variables & \multirow{2}{*}{$\mathbf{N}$} & \multirow{2}{*}{ Min } & \multirow{2}{*}{ Max } & \multirow{2}{*}{ Mean } & \multirow{2}{*}{ Std. Dev. } \\
\hline Outputs & & & & & \\
\hline DISC & 385 & 1.00 & 1180.00 & 159.57 & 180.02 \\
\hline INPDAY & 385 & 1.00 & 4517.00 & 687.20 & 766.90 \\
\hline \multicolumn{6}{|l|}{ Inputs } \\
\hline PHSY & 385 & 4.00 & 1480.00 & 130.76 & 174.22 \\
\hline NURSE & 385 & 1.00 & 230.00 & 39.69 & 41.40 \\
\hline BED & 385 & 2.00 & 157.00 & 28.91 & 28.79 \\
\hline VENT & 385 & 1.00 & 79.00 & 14.57 & 16.90 \\
\hline MONT & 385 & 2.00 & 158.00 & 27.11 & 27.15 \\
\hline \multicolumn{6}{|c|}{ Control Variables } \\
\hline MORT & 385 & 0.00 & 0.67 & 0.09 & 0.09 \\
\hline IZOBED & 385 & 1.00 & 7.00 & 0.65 & 0.83 \\
\hline SERV1 & 385 & 0.00 & 1.00 & 0.83 & 0.38 \\
\hline SERV2 & 385 & 0.00 & 1.00 & 0.64 & 0.48 \\
\hline SERV3 & 385 & 0.00 & 1.00 & 0.38 & 0.49 \\
\hline \multicolumn{6}{|l|}{ Ineff. Effects } \\
\hline ТЕАСН & 385 & 0.00 & 1.00 & 0.17 & 0.38 \\
\hline BRANCH & 385 & 0.00 & 1.00 & 0.14 & 0.35 \\
\hline ROLE & 385 & 1.00 & 4.00 & 2.31 & 1.10 \\
\hline
\end{tabular}

\subsubsection{Input and Output Variables}

Labor input used in a hospital consists of various occupations that have different effects on the production of the health care service. But in the intensive care units the most important inputs, which effect the output, are physicians and nurses. In the models both of these proficiencies are used as inputs and named PHSY and NURSE respectively. The other input variables that are used in the models proxies the capital input. BED is the total number of beds in ICUs. The other variables are VENT, which is the total number of ventilators and MONT is the total number of monitors in ICUs.

In the literature, there is no yet a consensus on the correct measure of inpatient activity in a hospital. Whether to choose patient days or discharges as a measure of inpatient care output depends on the hospitals' internal conditions. Li and Rosenman (2001) suggest the use of discharges when the majority of the costs for a patient is incurred by the visit, indicating that most costs are fixed. However, labor is a variable input and its use is usually dependent on the number of patient days rather than the number of discharges. Therefore, they recommend to use patient days as a measure of 
inpatient care output. On the other hand Rosko and Mutter (2008) suggest to use discharges as a measure of inpatient care output. They claim that the use of the patient days has several disadvantages since the magnitude of patient days could be affected by the differences in hospitals' discharge planning, quality improvements or by the variations in case-mix. Grannemann, Brown, and Pauly (1986) suggest the use of a combination of the two variables in order to analyze both of the hotel service and treatment aspects of health care delivered in hospitals. Following Grannemann et al. (1986), two different output variables used in the model. DISC is the number of total discharges, and INPDAY is the total inpatient days of the analyzed ICU.

\subsubsection{Control Variables}

The hospitals and their ICUs' outputs are heterogeneous with respect to case-mix complexity, intra-diagnosis related group (DRG) severity of illness, and quality. On the other, hand the inputs are also heterogeneous in terms of experience, knowledge, infrastructure and quality. For that reason, as common concern, if adequate controls for these dimensions are not used, lower costs associated with a less resource intensive case-mix or lower quality (i.e., due to fewer inputs per unit of output) might be associated with reduced inefficiency (Rosko and Mutter, 2008). In order to overcome such a shortcoming, some control/product mix descriptor variables, as well as quality variables are used in the SFA estimations. In this paper, five different control variables are used in the models.

Following Linna and Häkkinen (2006), Rosko and Mutter (2008) and Atilgan and Çalişkan (2015), the mortality rates are used as a proxy for quality of health care and this variable is named MORT. As there is a lack of data, risk adjusted mortality rates could not be used, which would be a much better proxy for quality measurement in the analysis. On the other hand, DRG based case-mix index is also not used in the analysis. These can be seen as the potential weakness of this paper. The other quality variable IZOBED, which counts for the number of ICU beds per isolation room, is used as a proxy for the infrastructure of the facilities. The other three variables SERV1, SERV2 and SERV3 are the dummy variables used to describe the technology level of ICUs based on the MoH's classifications. The upper level of ICU serves better technologies for the treatment of more severe cases.

\subsubsection{Inefficiency Effects}

Inefficiency effects variables are the firm specific and/or environmental variables that are thought to effect the efficiency scores. In the models, three different inefficiency effects variables are used. These variables are used to impose and evaluate the effects of hospitals' type and capacity on the efficiency scores. TEACH is a dummy variable that describes the hospitals' teaching status and has the value 1 if the hospital is a teaching hospital. BRANCH is a dummy variable and has the value 1 if the hospital is a branch hospital, so the general hospitals have the value 0. ROLE is an index which is 
based on the MoH's hospital role grouping scheme, that proxies the level of technology and the health care delivery of hospitals. ROLE has the value of 1 for the lowest group hospitals (Role group C hospitals), and 4 for the highest group (Role group A1 hospitals).

\section{ESTIMATION RESULTS}

The input-oriented and output-oriented SFA technical efficiencies are estimated using the Frontier 4.1 computer software. In order to estimate the output-oriented model shown in Equation (19), the output variable DISC is used to normalize the equation. In the input-oriented model, PYSY is used to normalize Equation (20).

In the models, all input and output variables are expressed in deviations from their sample means. This is simply a change in the units of measurement and does not change the underlying data; however, it has the advantage that the estimated first-order parameters in the translog function can now be directly interpreted as estimates of the input/output and scale elasticities evaluated at the sample means (Coelli, Estache, Perelman, and Trujillo, 2003, pp. 57-59).

The first order parameter estimates of the models, control variables and inefficiency effects are given in Table (2).The results in Table (2) suggest increasing returns to scale for both models sincethe scale elasticities $\epsilon_{X, Y}<1$ and $\epsilon_{Y, X}>1$. As expected, the estimated parameter of INPDAY is negative and requires input usage more than DISC. In both the input and output distance models, input variables, except MONT, found significant $(\mathrm{p}<0.05)$. The parameters of inefficiency effects variables TEACH and BRANCH are negative and significant $(\mathrm{p}<0.05)$. This implies that being a teaching or/and branch hospital contributes to efficiency scores. In both models, lambda $\gamma=\sigma_{u}^{2} /\left(\sigma_{u}^{2}+\sigma_{v}^{2}\right)$ is estimated to be around 0.81 and according to this results, $\% 81$ of deviations from the frontier stem from the inefficiencies. 
Table 2. Estimated Model Parameters (First Orders)

\begin{tabular}{|c|c|c|c|c|}
\hline Variables & \multicolumn{2}{|c|}{ Input-Oriented } & \multicolumn{2}{|c|}{ Output-Oriented $^{(1)}$} \\
\hline Outputs & Est. & St. Dev & Est. & St. Dev \\
\hline DISC & $-0.109 * *$ & 0.330 & - & - \\
\hline INPDAY & $-0.385^{*}$ & 0.164 & $-0.72 *$ & 0.244 \\
\hline \multicolumn{5}{|l|}{ Inputs } \\
\hline PHSY & - & - & $0.290 *$ & 0.186 \\
\hline NURSE & $0.385^{*}$ & 0.169 & $0.492 *$ & 0.315 \\
\hline BED & $0.158 *$ & 0.207 & $0.408 *$ & 0.676 \\
\hline VENT & $0.0510^{* *}$ & 0.635 & $0.060 * *$ & 0.285 \\
\hline MONT & $0.0584 * * *$ & 0.179 & $0.0485 * * *$ & 0.668 \\
\hline \multicolumn{5}{|l|}{ Control Variables } \\
\hline MORT & $-0.179 *$ & 0.125 & 0.003 & 0.003 \\
\hline IZOBED & $-0.041 *$ & 0.015 & $-0.273 * *$ & -0.273 \\
\hline SERV1 & -0.010 & 0.031 & 0.013 & 0.013 \\
\hline SERV2 & $-0.246 * *$ & 0.034 & 0.006 & 0.006 \\
\hline SERV3 & $-0.183 * *$ & 0.042 & $0.034 * *$ & 0.034 \\
\hline \multicolumn{5}{|l|}{ Ineff. Effects } \\
\hline TEACH & $-0.627 * *$ & 0.227 & $-1.741 *$ & 1.316 \\
\hline BRANCH & $-1.890 * *$ & 0.843 & $-0.859 * *$ & 0.724 \\
\hline ROLE & 0.108 & 0.052 & 0.764 & 0.323 \\
\hline$\sigma_{U}^{2}$ & 0.125 & 0.028 & 0.274 & 0.139 \\
\hline$\gamma=\sigma_{u}^{2} /\left(\sigma_{u}^{2}+\sigma_{v}^{2}\right)$ & 0.817 & 0.054 & 0.807 & 0.114 \\
\hline Log-likelihood & \multicolumn{2}{|c|}{85.848} & \multicolumn{2}{|c|}{-97.133} \\
\hline Scale Elasticity & \multicolumn{2}{|c|}{$\epsilon_{X, Y}=0.494$} & \multicolumn{2}{|c|}{$\epsilon_{Y, X}=1.299$} \\
\hline \multicolumn{5}{|c|}{$\begin{array}{l}{ }^{(1)} \text { All output distance function models parameters are multiplied by }(-1) \text { in order to be comparable } \\
\text { with the other model. } \\
*, * * \text { and } * * * \text { indicates significance at levels } \% 1, \% 5 \text { and } \% 10 \text { respectively. }\end{array}$} \\
\hline
\end{tabular}

The mean efficiency scores obtained from the input-oriented and the output oriented models are shown in Table (3). The mean inefficiency of the sample ICUs is found to be $\% 12$ (mean efficiency score $=0.88$ ) in the input-oriented efficiency model that represents the degree to which a hospital could decrease its input use without changing its outputs. On the other hand, the mean output-oriented inefficiency that represents the degree to which a hospital could expand its output without changing input use in ICUs, is estimated \%21.

Teaching hospitals are more efficient than the other hospitals in both input-oriented model and output-oriented model. Likewise, the branch hospital ICUs are tent to be more efficient than the others. On the other hand, the mean efficiency scores increase with an enlargement of the hospital size. As seen at the Table (3), the mean efficiency scores increase with the higher role group classifications. 
Table 3. Mean Efficiency Scores

\begin{tabular}{|c|c|c|c|c|c|c|c|c|c|c|}
\hline \multirow{2}{*}{\multicolumn{2}{|c|}{$\begin{array}{l}\text { HOSPITAL TYPES and } \\
\text { ROLE GROUPS }\end{array}$}} & \multirow{3}{*}{$\begin{array}{c}\text { MEAN } \\
\text { EFF. } \\
0,82\end{array}$} & \multicolumn{4}{|c|}{ Input-Oriented Efficiency Scores } & \multicolumn{4}{|c|}{ Output-Oriented Efficiency Scores } \\
\hline & & & \multirow{2}{*}{$\begin{array}{r}\text { Mean } \\
0,87\end{array}$} & \multirow{2}{*}{$\begin{array}{r}\text { Min. } \\
0,41\end{array}$} & \multirow{2}{*}{$\begin{array}{l}\text { Max. } \\
0,97\end{array}$} & \multirow{2}{*}{$\begin{array}{c}\text { Std. } \\
\text { Dev. }\end{array}$} & \multirow{2}{*}{$\begin{array}{r}\text { Mean } \\
0,76\end{array}$} & \multirow{2}{*}{$\begin{array}{r}\text { Min. } \\
0,31\end{array}$} & \multirow{2}{*}{$\begin{array}{l}\text { Max. } \\
0,95\end{array}$} & \multirow{2}{*}{$\begin{array}{c}\text { Std. } \\
\text { Dev. }\end{array}$} \\
\hline TEACHING & Others & & & & & & & & & \\
\hline STATUS & Teaching & 0,92 & 0,92 & 0,62 & 0,97 & 0,05 & 0,91 & 0,53 & 0,95 & 0,06 \\
\hline \multirow{2}{*}{$\begin{array}{l}\text { BRANCH } \\
\text { STATUS }\end{array}$} & Others & 0,83 & 0,86 & 0,41 & 0,96 & 0,08 & 0,80 & 0,31 & 0,95 & 0,14 \\
\hline & Branch & 0,85 & 0,96 & 0,93 & 0,97 & 0,01 & 0,75 & 0,32 & 0,94 & 0,20 \\
\hline \multirow{6}{*}{$\begin{array}{c}\text { ROLE } \\
\text { GROUPS }\end{array}$} & A1 & 0,92 & 0,90 & 0,62 & 0,95 & 0,05 & 0,93 & 0,87 & 0,95 & 0,02 \\
\hline & A1_Branch & 0,92 & 0,96 & 0,94 & 0,97 & 0,01 & 0,87 & 0,53 & 0,94 & 0,09 \\
\hline & $\mathrm{A} 2$ & 0,87 & 0,85 & 0,53 & 0,95 & 0,08 & 0,89 & 0,64 & 0,95 & 0,06 \\
\hline & A2_Branch & 0,82 & 0,96 & 0,93 & 0,97 & 0,01 & 0,67 & 0,32 & 0,91 & 0,20 \\
\hline & B & 0,81 & 0,84 & 0,41 & 0,96 & 0,08 & 0,78 & 0,37 & 0,94 & 0,09 \\
\hline & $\mathrm{C}$ & 0,78 & 0,87 & 0,49 & 0,96 & 0,08 & 0,69 & 0,31 & 0,95 & 0,17 \\
\hline
\end{tabular}

\section{CONCLUSION}

This paper presents an alternative econometric efficiency analysis tool for hospitals and hospital ICUs that has multiple input-out production technologies. The results of the paper suggest significant increasing returns to scale for both models, that implies, from an administrative point of view, a situation where there is an incentive to centralize operations.

The mean efficiency of the teaching hospitals' and branch hospitals' ICUs are found to be higher than the other hospitals in both models. Moreover, the findings of the paper imply that there is a positive correlation between hospital capacity or/and technology and ICUs efficiency. As hospital capacity increases or/and the role group of the hospital levels up, the hospital efficiency increases significantly. Thus, the results suggest that teaching and branch hospitals make a more efficient use of resources. From an economic view, all these results suggest that policy makers could make a better planning strategy via centralizing the ICUs in large hospitals or specialized health centers. On the other hand, hospitals services could not be treated as other public services. Therefore, side with a strategy for centralizing the ICUs benefit from increasing returns to scale, the better health care serving strategy could be based on a referral chain system with efficient and effective patient transportation system should be implemented in health system.

These findings could be resulted from another aspect related with case-mix or/and case-severity characteristics of hospitals. As teaching hospitals and also branch hospitals are expected to have a higher case-mix and treat more severe cases, the average patient days in these hospitals are higher than the other hospitals. This means that, ceteris-paribus, the total patient days of ICUs in teaching and branch hospitals would be more than the other hospitals. Therefore, the technical efficiency of these hospitals would be higher as a higher level of output is produced with a given input set. 


\section{REFERENCES}

Aigner, D. J., and Chu, S. F. (1968)“On Estimating the Industry Production Function”, American Economic Review, 58:826-839.

Aigner, D. J., Lovell, C. A. K. and Schmidt, P. (1977) "Formulation and Estimation of Stochastic Frontier Production Function Models", Journal of Econometrics, 6:21-37. doi: 10.1016/03044076(77)90052-5

Atilgan, E. (2015)“The Technical Efficiency of Outpatient Services In Turkish Public Hospitals: A Stochastic Frontier Estimation", International Healthcare Management Conference (IHMC), Gumushane, Turkey.

Atilgan, E. and Çalişkan, Z. (2015) "The Cost Efficiency of Turkish Hospitals: A Stochastic Frontier Analysis",Iktisat Isletme ve Finans, 30(355):09-30.

Battese, G. E.and Coelli, T. J. (1995)“A Model for Technical Inefficiency Effects in a Stochastic Frontier Production Function for Panel Data", Empirical Economics, 20:325-332. doi: 10.1007/BF01205442

Berndt, E. R.and Christensen, L. R. (1973) "The Translog Function and the Substitution of Equipment, Structures, and Labor in US Manufacturing 1929-68”, Journal of Econometrics, 1(1):81-113.

Caves, D., Christensen, L. and Tretheway, M. (1980) "Flexible Cost Functions for Multiproduct Firms", The Review of Economics and Statistics, 477-481.

Christensen, L., Jorgenson, D.and Lau, L. (1973)“Transcendental Logarithmic Production Frontiers”, The Review of Economics and Statistics, 55, 28-45.

Coelli, T. J., Estache, A., Perelman, S.and Trujillo, L. (2003)“A Primer on Efficiency Measurement for Utilities and Transport Regulators", WBI Development Studies.

Coelli, T. J.and Perelman, S. (1996)“Efficiency Measurement, Multiple-Output Technologies and Distance Functions: With Application to European Railways",CREPP, No: DP 1996/05.

Coelli, T. J., Rao, D. S. P., O'Donnell, C. J. and Battese, G. E. (2005) “An Introduction to Efficiency and Productivity Analysis", New York: SpringerScience\& Business Media.

Grannemann, T. W., Brown, R. S., and Pauly, M. V. (1986). Estimating Hospital Costs: A MultipleOutput Analysis. Journal of Health Economics, 5(2), 107-127.

Li, T. and Rosenman, R. (2001)“Cost Inefficiency in Washington Hospitals: a Stochastic Frontier Approach Using Panel Data", Health Care Management Science, 4(2):73-81.

Linna, M. and Häkkinen, U. (2006) "Reimbursing for the Costs of Teaching and Research in Finnish Hospitals: a Stochastic Frontier Analysis", International Journal of Health Care Finance and Economics, 6(1):83-97. 
Meeusen, W. and Van den Broeck, J. (1977)“Efficiency Estimation from Cobb-Douglas Production Functions with Composed Error", International economic review, 18:435-444. doi: $10.2307 / 2525757$

Özgen, H., Sahin, I. and Gülcü, A. (2008) "Veri Zarflama Analizi İle Üniversite Hastanelerinin Verimlilik Ölçümü”, Sağlık ve Hastane İdaresi Kongresi, Ankara.

Puig-Junoy, J.andRué-Monné, M. (1998) “Technical Inefficiency in the Production of Intensive Care Units”, International Journal of Operations and Quantitative Management, 4:23-42.

Richmond, J. (1974) "Estimating the Efficiency of Production", International Economic Review, 15:515-521.

Rosko, M. and Mutter, R. (2008)“Stochastic Frontier Analysis of Hospital Inefficiency: A Review of Empirical Issues and an Assessment of Robustness", Medical Care Research and Review, 65:131-166.

Sahin, I. (2009) "Sağlık Bakanlığı'na Devredilen SSK Hastanelerinin Teknik Etkinliği ve Toplam Faktör Verimliliği Analizi”,Iktisat Isletme ve Finans, 24(283):9-40.

Sahin, I.andOzcan, Y. A. (2000)"Public Sector Hospital Efficiency for Provincial Markets in Turkey", Journal of Medical Systems, 24(6):307-320.

Sahin, I., Ozcan, Y. A.and Ozgen, H. (2011) "Assessment of Hospital Efficiency under Health Transformation Program in Turkey”, Central European Journal of Operations Research, 19(1):19-37.

Shepherd, R. W. (2015)“Theory of Cost and Production Functions”, Princeton University Press.

Wagstaff, A. (1989)“Estimating Efficiency in the Hospital Sector: a Comparison of Three Statistical Cost Frontier Models", Applied Economics, 21(5):659-672.

Winsten, C. B. (1957)“Discussion on Mr. Farrell's Paper”, Journal of the Royal Statistical Society: Series A (General), 120:282-284. 